\title{
INTERPRETACJA CZYNNIKÓW OPERACYJNYCH W REGULAMINACH I DOKTRYNACH WYBRANYCH PAŃSTW W KONTEKŚCIE WALKI Z TAK ZWANYM PAŃSTWEM ISLAMSKIM
}

Interpretacja czynników operacyjnych w kontekście potencjalnej operacji wojskowej przeciwko Daesh (to arabski akronim od skrótu "ISIS” - ang. Islamic State of Iraq and Syria), wymaga określenia czynników operacyjnych, dzięki którym przyszłe działania przyniosłyby oczekiwane efekty.

Dotychczasowe operacje oraz misje wojskowe ukazały, że „czynnik operacyjny” dalej jest niezidentyfikowany. W tym aspekcie, brane są pod uwagę czynniki operacyjne Sojuszu Północnoatlantyckiego. Wobec zmieniających się warunków sytuacji geopolitycznej oraz dynamiki współczesnych konfliktów, należy określić ich istotę oraz wykazać obszary, które w dalszym ciąu, świadczą o niezrozumieniu ich przydatności. Czynniki operacyjne rozpoczęto identyfikować w ,sztuce wojennej” po pojawieniu się „operacji”. W tym sensie miały być tym, co na poziomie operacyjnym służy do identyfikacji, diagnozy i prognozy prowadzenia potencjalnych działań. Dlatego zasadna jest teza, iż czynniki operacyjne to nie element operacji, a kierunki wskazujące na zasadności określonych działań. Dlatego też czynniki operacyjne nie mogą być analizowane jedynie na poziomie operacyjnym. Planowanie wymaga ich identyfikację, na wszelkich poziomach działań, ponieważ przez ich znajomość można zaplanować racjonalne działanie. Dlatego czynniki operacyjne w badanym kontekście będą rozumiane jako zespół w miarę stałych elementów, których aspekt pozytywny lub negatywny w sposób istotny wpływa na organizację i metody osiagania celu. Wnioski z analizy czynników operacyjnych umożliwiają ocenę warunków osiagania celu, a relacje pomiędzy nimi dokonać wyboru odpowiedniej metody działania. Ocena czynników operacyjnych i relacji pomiędzy nimi jest podstawą myślenia i planowania operacyjnego.

W teorii problemu czynniki operacyjne nie sąjednoznacznie postrzegane i interpretowane $z$ wielu przyczyn. Jedną z nich jest próba przypisania czynnikom operacyjnym znaczenia zasad i odnoszenia ich tylko do operacji. Inne nieporozumienia wynikają z uproszczonych tłumaczeń z języka angielskiego na język polski, co powoduje, że czynniki operacyjne nabierają znaczenia taktycznego działania, co zatraca ich ideę. Kwestia praktyczna wykorzystania istoty czynników operacyjnych jest o tyle istotna, iż ich oprawna identyfikacja umożliwi jasne celowe działania, umożliwiające podjęcie działań poszczególnym komponentom wojskowym.

W niniejszym artykule, głównym przedmiotem badań jest teoria sztuki wojennej w aspekcie identyfikacji czynników operacyjnych i ich potencjalnych interrekacji w kontekście walki z Daesh. Wyniki dotychczasowych operacji, nie dają jednoznacz- 
ności, żeby w procedurach poznania naukowego dokonać rozstrzygnięć. Stąd w procesie badań poszukiwano źródeł czynników operacyjnych, których nie definiowano w sztuce wojennej przed powstaniem operacji, ale posługiwano się ich założeniami w sposób intuicyjny.

Czynniki operacyjne. Obecnie na poziomie operacyjnym występują znaczące przewartościowania. Zmieniają się też priorytety w działaniach dowódców operacyjnych. Elementy takie jak: cel, sily (baza operacyjna), środowisko działań, czas, przeciwnik stanowią stałe jakościowe i ilościowe.

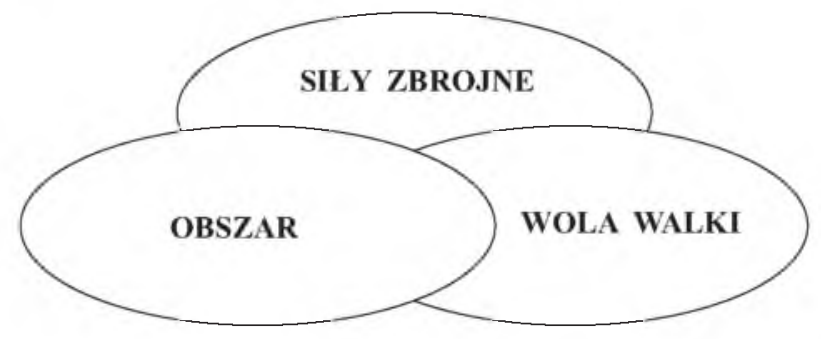

Rys. 1. Czynniki wojny jako czynniki operacyjne

Źródlo: Opracowanie własne na podstawie: C. Clausewitz (1993), $O$ wojnie, Lublin.

Oddziałują one na możliwość działania i obszar swobody dowódców poziomu operacyjnego. Przedmiotem zainteresowania w tym kontekście stają się czynniki operacyjne. Ich określenie i zbadanie stopnia wpływu na poziomie operacyjnym staje się istotnym elementem wspomagającym proces decyzyjny i przyjmowane koncepcje funkcjonalne w tym zakresie. „Czynnik” w tym kontekście jest rozumiany jako jedna z przyczyn działających i wywołujący skutek. Jako jeden ze składników, rozstrzygających o czymś w decydujący i istotny sposób. To leksykalne ujęcie terminu „czynnik” ma swe odniesienie do problematyki działań operacyjnych i może mieć zastosowanie co do możliwości działania wojsk własnych, a także przeciwnika oraz określenie optymalnego stosunku między nimi w zależności od rodzaju działań i zadania.

Zadaniem dowódców poziomu operacyjnego, stanowiącego element łączący działania na szczeblu taktycznym z działaniami szczebla strategicznego jest racjonalne planowanie i prowadzenie walki na płaszczyźnie optymalnego zagospodarowania przestrzeni zadaniowej.

Osiaganie celów strategicznych odbywa się na szczeblu operacyjnym. Działalność szczebla operacyjnego musi bezpośrednio przyczyniać się do osiagnięcia wcześniej określonych celów strategicznych, które wynikająz ogólnych politycznych celów operacji. W skali operacyjnej stan końca operacji jest ściśle związany z zaplanowanym poziomem osiagnięcia celu operacji, który powinien obejmować wszystkie z niżej przedstawionych warunków: Pożądany stan lub rezultat, w którym znalazł się element działający, do którego planowano proces działań celowych - decyzyjny - zgodnie ze sformułowanym zadaniem - i dla którego osiągnięcia planowano i wykonano wszystkie przedsięwzięcia. Sytuacja była przewidywana i uwzględniała niezbędną reorganizację systemu działań. 
W ujęciu systemowym lub materialnym podmiot działania posiadł, zdobył lub znalazł się w określonej sytuacji, przy uwzględnianiu aspektów rzeczowego, czasowego, przestrzennego lub w integracji tych czynników. Obiekt celowych działań (jednostkę organizacyjną lub zbiór jednostek - szczebel operacyjny) zachowuje zdolność do utrzymania tego stanu lub sytuacji i jest świadomy swej roli w systemie, w którym działa.

Standard określa minimalny poziom, który można uznać za świadectwo osiagnięcia celu. Wskazuje on, że przewidywany wynik został osiagnięty w takim stopniu, który zapewnia możliwość dalszego działania, po wykorzystaniu rezultatów osiagnnięcia celu, lub może oznaczać tylko zdolność do utrzymania stanu posiadania.

Czynnik polityczno-wojskowy wg Doktryny D 0/1 oraz dokumentów AJP łączy poziom wojskowy i cywilny w NATO. Zapewnia przepływ dyrektyw militarnych, do nadrzędnych organizacji oraz ich przetworzenie na wytyczne polityczne ukierunkowane na podległe struktury dowodzenia. Na tym poziomie strategiczne cele polityczne zamieniane są na strategiczne cele militarne $\mathrm{z}$ jednoczesnym określeniem pożądanego stanu końcowego. Działalność wojskowa na wszystkich szczeblach może negatywnie wpływać na lokalną lub międzynarodową sytuację polityczną. Dlatego też czynnik wymiaru politycznego we wszystkich rodzajach prowadzonych operacji, wymaga wnikliwego rozważenia. Oznacza to iż, dowodzący na szczeblu operacyjnym niejednokrotnie będzie potrzebował od swojego przełożonego lub od nadrzędnych organów dowodzenia wskazówek w tym zakresie. Istota czynnika cywilno-wojskowego ma ponadto zastosowanie w połączonych operacjach we współpracy $\mathrm{z}$ agendami rządowymi i pozarządowymi. Udowadnia to fakt, iż działania operacyjne niekoniecznie muszą być prowadzone z użyciem siły militarnej lub groźby jej użycia. Dlatego bardzo ważne jest skategoryzowanie celów misji lub operacji, uwzględniając cele zarówno polityczne, militarne, jak i cele ludności cywilnej oraz instytucji w obszarze operacji. Operacje tego typu będą charakteryzować się bardziej złożonym planowaniem wielofunkcyjnym. Wieloaspektowe sytuacje kryzysowe zwykle angażują wiele organów politycznych i rozmaite agencje, a także organizacje międzynarodowe. W takich sytuacjach rola CIMIC wciąż pozostanie pierwszoplanowym zagadnieniem. Podstawowa wiedza z zakresu życia regionu umożliwi kontakt z miejscową ludnością, który zapobiegnie nieporozumieniom i konfliktom wynikającym z nieznajomości lokalnej kultury cywilizacyjnej, języka, obyczajów i religii (Command and Control of Land Forces (TF) HDv 100/100, 2007: Appendix 1).

Kolejnym elementem jest swoboda działania, to czynnik, w którym dowódca operacyjny ma obowiązek opracowania koncepcji, zaplanowania i skoordynowania wszystkich działań militarnych niezbędnych do uzyskania oraz utrzymywania inicjatywy w sposób umożliwiający mu rozstrzygnięcie wielu walk na swoją korzyść. Osiaga w ten sposób długofalowe cele strategiczne. Zachowanie swobody działania dowódcy, dla umożliwienia reagowania w niespodziewanych sytuacjach, ustalenia priorytetów, wykorzystania nadarzających się okazji, wprowadzenia lub przydzielenia morskich, lądowych lub lotniczych odwodów. Stopień swobody działania na szczeblu operacyjnym będzie zależał od natury konfliktu, oddziaływania militarnych i pozamilitarnych ogniw w ramach kolektywnej, ogólnej strategii oraz skali zagrożenia interesów Sojuszu. Po rozpoznaniu tych ograniczeń, dowódca ogłasza jasną deklarację swoich zamia- 
rów, w której określa koncepcję działań i ustanawia cele, jakie mają osiaggnąć podlegli mu dowódcy, umożliwiając swobodę działania na niższych szczeblach.

Kolejny czynnik operacyjny to współpraca z mediami, to element, który będzie wprowadzać na wszystkich szczeblach dowodzenia strategię informacyjną NATO. Ważnym punktem wpływającym na morale sił połączonych jest przychylność relacji mediów mające duże znaczenie w utrzymaniu publicznego poparcia i życzliwości społeczności międzynarodowej. Należy mieć na uwadze, że media posiadają olbrzymi wpływ na międzynarodową opinię publiczną, zarazem związaną z przeciwnikiem jak i własnym środowiskiem. Dostępność, obsługa oraz właściwe informowanie mediów będzie więc znaczącym i pozytywnym czynnikiem w połączonych oraz wielonarodowych operacjach.

Należy pamiętać, iż użycie siły militarnej w operacjach NATO muszą definiować stopień i sposób, w jakim mogą zostać użyte oraz niezbędne będzie opracowanie planu w celu ich użycia i zapewnienia kontrolowanego wykorzystania sił przez dowódcę szczebla operacyjnego. Podczas operacji wykorzystanie zasobów przez siły koalicyjne powinno być utrzymywane na poziomie zapewniającym ich najbardziej efektywne użycie. Nieodzowne będą działania dyplomatyczne, które spowodują umożliwienie dowódcy wykorzystania zasobów lokalnych, takich jak obiekty, materiały i usługi. Kraje członkowskie Sojuszu NATO uzgodniły procedury dotyczące obowiązków państwa gospodarza. Bardzo duże znaczenie na szczeblu operacyjnym ma zasada koncentracji sił wraz zjej następstwem w postaci ekonomii wysiłku. O ile nie będzie problemu z zastosowaniem jej przy pomocy krajów członkowskich NATO, to na wypadek operacji prowadzonych poza obszarem Sojuszu będzie konieczne prowadzenie negocjacji opartych na zawieraniu umów pomiędzy rządami i NATO lub w drodze ustaleń dwustronnych. Za zarządzanie przydzielonymi siłami i zasobami, prowadzenie i zabezpieczenie działań w celu osiągnięcia celów operacyjnych odpowiedzialny jest dowódca operacyjny. Ponadto prowadzenie tego typu działań przez Sojusz jest regulowane prawem międzynarodowym i podpisanymi konwencjami oraz prawami wewnętrznymi państw uczestniczących w operacji. Należy tu podkreślić, że prawo międzynarodowe niesie ze sobą ograniczenia i możliwości dla prowadzenia operacji, uwzględniając neutralność stron, zasady użycia broni, wybór celów, przestępstwa wojenne, samoobronę, osoby niewalczące, immunitety i ograniczenia środowiskowe.

Przedstawione czynniki operacyjne: cel, siły (baza operacyjna), środowisko działań, czas i przeciwnik, czynnik cywilno-wojskowy, media, swoboda działania - znajdują się w Doktrynie Działań Operacyjnych D 0/1. Będąc członkiem Sojusz NATO i uwzględniając obecne cele strategiczne zadaniem dowódców poziomu operacyjnego jest zbadanie tych czynników co do możliwości działania wojsk sprzymierzonych i przeciwnika oraz określenie optymalnego stosunku między nimi w zależności od rodzaju działań i zadania. Ich znaczenie będzie ulegało ciągłej zmianie. $Z$ uwagi na efektywność działań Sojuszu Północnoatlantyckiego oraz istotę współczesnych zagrożeń zerwana została idea oddzielnie wykorzystywanych środków dyplomatycznych, wojskowych, finansowych, porządkowych oraz prawnych. Srodki okazały się niewystarczające do współczesnych wyzwań bezpieczeństwa międzynarodowego. Dużo bardziej korzystne działania Sojusz Północnoatlantycki podejmuje poprzez zintegrowanie systemu oraz przy pomocy współpracy cywilno-wojskowej. Zaś do zasadniczych gwaran- 
tów uzyskania powodzenia podczas działań sojuszniczych i koalicyjnych zalicza się osiągnięcie przez zaangażowane strony założonego stopnia interoperacyjności, połączoność, która oznacza wspólną ocenę sytuacji, skoordynowane planowanie i podział zadań pozwalające na wykorzystanie możliwości rodzajów sił zbrojnych oraz wspólne kierowanie przebiegiem operacji połączonej oraz dyspozycyjność wojsk, która jest niezbędna do zapewnienia ciągłości prowadzenia działań. Operacje reagowania kryzysowego są prowadzone przez Sojusz Pólnocnoatlantycki z upoważnieniem Organizacji Narodów Zjednoczonych (El Ghamari, 2015: 47).

Do momentu wprowadzenia założeń dokumentu The Military Concept for NATO Peace Support Operations opracowanego przez Komitet Wojskowy - posługiwano się terminologią Organizacji Narodów Zjednoczonych w zakresie operacji reagowania kryzysowego (The Military Concept for, 1997). Używano terminu obejmującego szeroki zakres operacji reagowania kryzysowego spoza artykułu 5 (ang. Non-Article 5 Crisis Response Operations - NA5CRO).

$Z$ uwagi na powyższe, dokument Sojuszu Północnoatlantyckiego The Military Concept for NATO Peace Support Operations wprowadził dodatkowy podział operacji (schemat 7). Dokument wprowadził nowe pojęcie tzw. Peace Support Operations (PSO), co oznacza operacje wsparcia pokoju i stanowi wielofunkcyjne operacje prowadzone na zasadzie bezstronności, na podstawie mandatu ONZ/OBWE z zaangażowaniem: sił wojskowych, działań dyplomatycznych i humanitarnych w celu osiagnięcia długoterminowego porozumienia politycznego pomiędzy stronami konfliktu lub innych warunków sprecyzowanych w mandacie (Allied Joint Doctrine for Non-Article 5 , 2007).

Operacje wsparcia pokoju, obejmują zgodnie z klasyfikacją Sojuszu Północnoatlantyckiego następujące typy operacji:

- zapobieganie konfliktom,

- tworzenie pokoju,

- utrzymanie pokoju,

- wymuszanie pokoju,

- budowanie pokoju,

- operacje humanitarne (Allied Joint Doctrine, Peace Support Operations, 2010).

Zapobieganie konfliktom (ang. conflict prevention) to katalog różnych przedsięwzięć, którego podstawą jest rozdział VI Karty Narodów Zjednoczonych. Działania te obejmują środki:

- dyplomatyczne,

- polityczne,

- wojskowe/obronne,

- spoleczne,

- szkoleniowe,

- prewencyjne (Karta Narodów Zjednoczonych, 1945: Art. 33-38).

Ich celem jest zapobiegnięcie przekształceniu się lokalnego, regionalnego lub narodowego sporu w konflikt zbrojny oraz jego ewentualnemu rozprzestrzenieniu się. Działania, które są podejmowane w tym zakresie, zawierają w sobie elementy takie jak: ustalanie faktów, konsultacje, ostrzeżenia, inspekcje, nadzorowanie oraz obserwacje (Directive for NATO Doctrine for PSO, 1998: 11). W operacji wsparcia 
pokoju, jaką jest zapobieganie konfliktom, zastosowanie środków militarnych jest ostatecznością.

Państwa europejskie, mimo przynależności do organizacji międzynarodowych (NATO, Unia Europejska) posiadają swoje narodowe rozwiązania realizacji procesu dowodzenia na wszystkich poziomach. Przeprowadzone badania teoretyczne dokumentów doktrynalnych wybranych państw, pozwoliły wygenerować wnioski wskazujące podobieństwa i różnice w sposobie analizy i doborze czynników mających wpływ na planowanie i prowadzenie operacji.

W niniejszej części przedstawione zostaną rozwiązania przyjęte w siłach zbrojnych Niemiec i Wielkiej Brytanii. Szczegółowej analizie poddano zapisy zawarte w Regulaminie walki wojsk lądowych Bundeswehry, opracowane wnioski jednoznacznie wskazują, że podczas określania celów i planowania każdej operacji uwzględnia się siły, czas, obszar na którym ma być ona prowadzona oraz informację. Dodatkowo podkreślone są, zmieniające się w sposób ciągły, zależności pomiędzy powyższymi czynnikami. Należy dążyć do jak najszybszego dostrzeżenia tych zmian, wyciągnięcia wniosków i wybrania sposobów działania, zapewniających sukces, doskonaląc siły, ugrupowania wojskowe, sprawność wojsk, efektywność, skuteczność broni, organizację, wyposażenie, szerokość, głębokość, rozproszenie i koncentrację sił w zależności od sytuacji, zadania (misje), zamiar dowódcy oraz teren.

Analizując pokrótce powyższe czynniki, siły to odpowiednio do zadań ugrupowane wojska, które dowódca ma do dyspozycji w celu realizacji misji. Wojska muszą być odpowiednio zorganizowane i wyposażone. Ich możliwości bojowe wynikają z liczebności, rodzaju i stanu wyposażenia, stanu wyszkolenia, gotowości bojowej, systemu dowodzenia oraz kondycji fizycznej i psychicznej. Decydujące znaczenie ma ponadto osobowość dowódcy oraz duch bojowy żołnierzy. Sprawność wojsk znajdujących się bezpośrednio $\mathrm{w}$ walce określana jest mianem zdolności bojowej, zaś predyspozycje wojsk do realizacji konkretnego zadania to ich możliwości bojowe. Istotne jest to, żeby wojska były wykorzystywane zgodnie z ich przeznaczeniem. Efektywność sił przejawia się w sprawności i skuteczności użycia broni i innych środków do oddziaływania na przeciwnika, strony konfliktu lub poszczególnych grup w określonym czasie i na określonym obszarze. Wyznaczniki te określają przydatność sił dla danej misji. W przypadku sił wielonarodowych, ich efektywność zależy dodatkowo od uwarunkowań narodowych, uzgodnień w zakresie ujednolicenia systemu dowodzenia oraz interoperacyjności, sprawności jednostek logistycznych i medycznych, które są zwykle w gestii narodowej.

Wyznacznikiem w analizie sił, jako czynnika operacyjnego, jest również odpowiednia ich organizacja i wyposażenie. Skład i ugrupowanie wojsk musi być określone poprzez pryzmat zadań operacji, jakie przed nimi stoją, często powoduje to konieczność zmian podstawowej organizacji. Jednostki organizacyjne mogą być wzmacniane, zmniejszane lub organizowane jako kombinacja różnych rodzajów wojsk i sił zbrojnych.

Współczesne zagrożenia generują zadania, których wykonanie wymaga połączenia wysiłku poszczególnych rodzajów wojsk, a nawet sił zbrojnych. Analizując przypadek Bundeswehry rozwiązaniem jest integracja elementów w celu stworzenia grupy zadaniowej. Grupy takie tworzy się zwykle w sile stanowiącej ekwiwalent batalionu z ujednoliconym systemem dowodzenia i zabezpieczenia w celu zapewnienia jej zdolności 
bojowej. Niezwykle istotnym elementem w ramach analizy sił jest organizacja ugrupowania sił Bundeswehry. Szerokość, głębokość, rozproszenie i koncentracja sił, szczególnie w operacjach wojennych, określane są w zależności od sytuacji, zadania (misji), zamiaru dowódcy oraz terenu.

Należy pamiętać, że w oddziałach Bundeswehry, preferuje się wykorzystywanie organicznych jednostek, co gwarantuje odpowiedni poziom kompatybilności pomiędzy elementami ugrupowania, $w$ tym wspólne szkolenie, znajomość procedur planowania i dowodzenia. Powodem takiej organizacji jest, fakt, iż szerokie ugrupowanie umożliwia użycie większej ilości sił jednocześnie, jednakże utrudnia to szybką reorganizację. Zbyt szerokie ugrupowanie obniża spójność oraz siłę ataku i obrony. Z kolei zbyt wąskie ugrupowanie, ogranicza możliwość użycia sił jednocześnie. W sytuacji, kiedy intencją dowódcy jest szybkie natarcie, siły powinny być ugrupowane głęboko, zapewniając swobodę działania.

Dalsza interpretacja czynników, wskazuje na istotę stosowania przez siły NATO „rozproszenia i koncentracji sił”. Rozproszenie utrudnia przeciwnikowi ich rozpoznanie, maskuje zamiar dowódcy oraz redukuje zagrożenie oddziaływania przeciwnika. W walce, nadmierne rozproszenie, zmniejsza efektywność sił, zarówno nacierających, jak i broniących się oraz utrudnia możliwość szybkiej reakcji na pojawiające się zagrożenia. Koncentrację sił natomiast, przeprowadza się w celu realizacji zadań zdefiniowanych poprzez punkty decydujące. Musi ona przebiegać szybko, jednak tak późno jak to możliwe i tylko na taki czas, jaki jest niezbędny w danej sytuacji. Koncentracja i rozpraszanie sił $w$ zmiennych warunkach w obszarze operacji może spowodować powstanie luk i niezabezpieczonych obszarów w ugrupowaniu, co z kolei stwarza możliwości do przenikania, obejścia, a nawet okrążenia sił własnych przez przeciwnika.

Siły muszą dostosować swoje działania do czasu, jaki mają do dyspozycji. Celowe zagospodarowanie czasu zapewnia znaczne korzyści. Podczas prowadzenia operacji bardzo ważne jest, aby być szybszym od przeciwnika. Szybkość działania umożliwia uzyskanie korzyści czasowych, a tym samym zaskoczenie przeciwnika oraz utrzymanie lub też zdobycie swobody działania. Dążenie do szybkiego działania - również w sytuacjach kryzysowych - nie może jednak doprowadzić do pospiesznych poczynań.

Zasadnym jest również analiza „czasu”, jaki jest potrzebny do przeprowadzenia procesu dowodzenia. Należy jednak wykorzystać wszystkie możliwości jego skrócenia. Służy temu zwłaszcza stosowanie technologii informatycznych, dokładne uregulowanie wsparcia logistycznego i medyczno-sanitarnego, odpowiednio wczesne zaplanowanie i utworzenie systemu łączności oraz wstępne dokumenty rozkazodawcze, mające przygotować wojska do czekających je zadań.

Kolejnym elementem analizowanym $w$ ramach tego czynnika operacyjnego jest czas potrzebny do przygotowania operacji określany przez pryzmat wyboru i generacji sił, przemieszczenia ich do rejonu operacji oraz zintegrowania w ramach międzynarodowych struktur. Przestrzeń - określa rozmiar i charakteryzuje miejsce, w którym będzie prowadzona operacja, co ma duży wpływ na sposób działania i rodzaj zaangażowanych sił. Jest dzielona na:

- teatr operacji - terytorium określone przez mandat narodowy, na którym niemieckie siły zbrojne realizują swoje misje; 
- obszar operacji połączonej - przestrzeń przydzielona dowódcy połączonemu w celu prowadzenia operacji;

- obszar działania - przestrzeń określona przez dowódcę połączonego i przydzielona podległemu dowódcy w celu prowadzenia działań;

- obszar odpowiedzialności - przestrzeń, w której dowódcy na każdym poziomie dowodzenia mogą prowadzić operacje/działania, o której posiadają wszechstronną wiedzę (teren, pogoda, infrastruktura itp.) w zakresie korzyści i ograniczeń, jakie stwarza dla ich sil:

- obszar zaangażowania - część teatru operacji, w którym lub z którego niemieckie siły zbrojne realizują swoje misje;

- obszar zainteresowania - przestrzeń, poza obszarem odpowiedzialności, która jest istotna dla prowadzonej operacji lub gdzie wydarzenia mogą mieć wpływ na jej przebieg;

- pole walki - przestrzeń, w której toczone są działania zbrojne.

Każdy dowódca musi dokładnie poznać teren na swoim obszarze odpowiedzialności, aby wykorzystać sprzyjające warunki terenowe i co najmniej osłabić jego niekorzystne oddziaływanie (Command and Control of Land Forces, 2007: Appendix 1).

Regulamin HDv 100/100 identyfikuje również elementy zawierające się w powyższym czynniku operacyjnym, które mają zasadniczy wpływ na charakter działania i ugrupowanie sił na poziomie taktycznym. Przeprowadzone badania wskazuja, że do takich elementów należy rejon kluczowy definiowany jako cześć przestrzeni, której utrzymanie lub panowanie nad nią decyduje o powodzeniu operacji. W swoim planie operacji dowódca ustala czy rejon kluczowy ma zostać zajęty, utrzymany czy też w inny sposób ochraniany przed przeciwnikiem. Zwraca się jednak uwagę na to, aby podporządkowanym dowódcom określać rejon kluczowy tylko w wyjątkowych sytuacjach (ibidem).

Odpowiednio do zadań i potrzeb siłom przydziela się strefy, obszary, pasy i rejony. Wojska nie muszą w pełni wykorzystać przydzielonej im przestrzeni. Odpowiadaja jednak za jej rozpoznanie, ubezpieczenie i osłonę. Do zarządzania przestrzenią oraz koordynacji czasowej i przestrzennej wojsk wykorzystuje się linie dowodzenia.

Strefy, obszary, pasy oraz rejony określa się liniami rozgraniczenia. Linie te nie mogą być traktowane jako nieprzekraczalne granice. Nie mogą one również ułatwiać przeciwnikowi prowadzenia operacji. Dlatego też szczególnie starannie należy uregulować współdziałanie i wzajemne wspieranie się sąsiadujących wojsk.

Informacja - ma wpływ na planowanie, dobór oraz wykorzystanie sił i środków we wszystkich rodzajach operacji. Zbieranie, przetwarzanie i dystrybucja wymaganych informacji dotyczących realizacji misji jest podstawą sukcesu w każdej sytuacji. Tu jednakże pojawia się problem. Bowiem w dobie zbyt dużej ilości informacji wymagana jest niezwykła precyzja analityków oraz sił wywiadowczych, które odseparują propagandę medialną od faktów. Do tego należy dołączyć informacje, które są wysyłane w świat celowo, by zmylić podejmowanie jakichkolwiek działań specjalnych w terenie operacyjnym. W dokumentach doktrynalnych, można przeczytać, że dowódcy na wszystkich poziomach dowodzenia nie mogą czekać na informacje, przeciwnie oni muszą ją zdobywać nawet przy użyciu siły. Tu w mojej osobistej opinii, pojawia się błąd taktyczny. Działania muszą podlegać planowaniu, ale należy wziąć pod uwagę głównie dostępne źródła informacji z danego obszaru. By celowo przeprowadzać ope- 
racje, należy wcześniej mieć przygotowaną bazę wywiadowczą na danym terenie. Nie mogą to być przypadkowe osoby, tak samo jak źródła informacji, znajdujące się w teatrze działań zbyt krótko. Niestety, siatkę buduje się przez lata, dlatego tak trudno w obliczu obecnego zagrożenia przeprowadzić jakiekolwiek działania. Normy oraz dokumenty doktrynalne stają się naszym przeciwnikiem. Zapisy, jakie zostały przedstawione powyżej w teorii się zgadzają, ale w praktyce pojawia się wiele czynników, których nie da się zaplanować - dlatego będą nazywane czynnikiem ludzkim, bowiem tylko on jest nieprzewidywalny. Organizacja poziomych i pionowych więzi informacyjnych, systemu łączności oraz sposobu zarządzania jest kluczowa dla właściwej dystrybucji informacji i tworzenia obrazu sytuacji operacyjnej, co z kolei jest warunkiem koniecznym działania sieci oraz zapewnienia że funkcjonują systemy rozpoznania, dowodzenia i zaangażowania sił. Dowódca musi być świadomy potencjału i możliwości systemu wymiany informacji, ale również jego ograniczeń i słabości.

Informacje zgromadzone przez wywiad i rozpoznanie stanowią podstawę do oceny możliwości i prawdopodobnego zamiaru działania przeciwnika lub stron konfliktu. Dowódcy muszą posiadać możliwie aktualny obraz sytuacji operacyjnej przez cały czas, zapewniając sobie przewagę informacyjną. To z kolei pozwala im, po pierwsze, zdobyć przewagę pod względem czasu, a po drugie, przewagę pod względem działania. Przewaga informacyjna jest kluczowa dla uzyskania i utrzymania inicjatywy w operacji. Dowódca musi oddziaływać informacyjnie na przywódców i siły przeciwnika lub stronę przeciwną oraz miejscową ludność (społeczeństwo).

Zdobywanie informacji jest ciagłym wysiłkiem $w$ ramach całościowej wiedzy sytuacyjnej, obejmującej przeciwnika lub strony konfliktu, siły sprzyjające i inne czynniki, które mają zasadniczy wpływ na operację. Proces ten jest konieczny, aby umożliwić dowódcy podejmowanie decyzji na podstawie najbardziej aktualnej informacji.

Celem oddziaływania informacyjnego jest wpływ na siły przeciwnika, strony konfliktu oraz osoby będące pod ich kontrolą tak, aby doprowadzić do zmiany w ich zachowaniu. Szczególnie w operacjach o małej i średniej intensywności, takie oddziaływanie przyczynia się do tworzenia i utrzymania poczucia zaufania w przestrzeni operacyjnej, a tym samym do poprawy bezpieczeństwa zaangażowanych sił. Informacja wykorzystywana jest również do oddziaływania na system dowodzenia przeciwnika lub stron konfliktu. W zależności od zamiaru dowódcy oddziaływanie takie może być prowadzone w celu zakłócenia, wprowadzenia w błąd, zneutralizowania, manipulowania, sparaliżowania lub zniszczenia systemu dowodzenia i rozpoznania.

Dostarczenie żołnierzom aktualnej i prawdziwej informacji powoduje zbudowanie i utrzymanie ich zaufania do dowódców oraz redukuje skutki oddziaływania informacyjnego przeciwnika.

Przeprowadzone badania dokumentów doktrynalnych stosowanych w Wielkiej Brytanii pozwoliły zidentyfikować obszary zainteresowania w czasie analizy czynników, które mają wpływ na planowanie i prowadzenie operacji. Według doktryny pt. Planowanie kampanii we współczesnym środowisku operacyjnym, charakter wojny pozostaje niezmienny, ale charakter konfliktu się zmienia. $Z$ tego względu, mimo wniosków i doświadczeń z minionych konfliktów, koniecznym jest reagowanie na zachodzące zmiany. Właściwa ich interpretacja określi możliwe działania. W tym celu należy poznać aktualną sytuację z odpowiednią szczegółowością tak, aby zminimalizo- 
wać możliwość całkowitego zaskoczenia. W dokumentach doktrynalnych Wielkiej Brytanii szczególny nacisk kładzie się na właściwe zrozumienie powstałej sytuacji kryzysowej (ang. situational understanding) jako wstęp do efektywnego planowania poprzez identyfikację problemu do rozwiązania. W tym celu zdefiniowano obszary, które będą poddawane szczegółowej analizie:

- identyfikacja okoliczności i otoczenia danej sytuacji kryzysowej, zarówno z obecnego, jak i historycznego punktu widzenia;

- analiza potencjalnych źródeł konfliktu, zwłaszcza tych, które wydają się być najważniejsze.

W ramach analizy prowadzącej do zrozumienia sytuacji kryzysowej dowództwa poziomu operacyjnego analizują obiekty i czynniki wpływające na zaistniałą sytuację. Obiekty to siły i środki, na które będzie skierowane oddziaływanie. Sztab ocenia okoliczności, otoczenie, uczestników i ich wpływ na środowisko operacyjne, określając jednocześnie możliwe oddziaływanie na przebieg operacji.

Powyższe czynności realizuje się $w$ ramach oceny operacyjnej, która jest logicznym procesem rozumowania (postępowania), w którym dowódca, w obliczu zaistniałej sytuacji kryzysowej, podejmuje decyzje dotyczące koniecznych działań, aby wypełnić misję. Ocena operacyjna powinna skupić się na podstawach problemu militarnego oraz na możliwościach, jakie stwarzają główne czynniki, takie jak zdolności, zasoby, zasadność, czas i przestrzeń (Joint Doctrine Publication, 2008: 10-16).

Przeprowadzone badania dokumentów doktrynalnych Wielkiej Brytanii wskazują, że analiza czynników operacyjnych obejmuje szczegółową ocenę środowiska operacyjnego, grupując jego elementy w sposób odmienny niż tradycyjnie przyjęty podział na przestrzeń, siły, czas i informacje.

Badanie oparto na następujacych dokumentach:

- British Defence Doctrine ( $4^{\text {th }}$ Edition);

- Defence Strategic Direction;

- The DCDC Global Strategic Trends - Out to 2040;

- JDP 01 Campaigning $\left(2^{\text {nd }}\right.$ Edition);

- JDP 04, Understanding;

- JDP 2-00 Understanding and Intelligence Support to Joint Operations ( ${ }^{\text {rd }}$ Edition);

- JDP 3-00 Campaign Execution ( ${ }^{\text {rd }}$ Edition, Change 1);

- JDP 3-40 Security and Stabilisation: The Military Contribution;

- JDP 4-00 Logistics for Joint Operations ( $3^{\text {rd }}$ Edition);

- JDP 6-00 Communications and Information Systems Support to Joint Operations $\left(3^{\text {rd }}\right.$ Edition, Change 1$)$;

- AJP 5-00 Allied Joint Doctrine for Operational-Level Planning;

- Allied Command Operations Comprehensive Operations Planning Directive (Interim version 1.0);

- JDP 5-00 Allied Joint Publication (AJP)-01 Allied Joint Doctrine;

- AJP-3 Allied Joint Operations;

- AJP-5 Allied Joint Operational-Level Planning;

- AJP 5 Operational-level planning (with UK supplement);

- Comprehensive Operations Planning Directive (COPD);

- JDP 5-00 Campaign Planning (ibidem: 8). 
Realizując zasady zapisane w powyższych dokumentach, w siłach zbrojnych Wielkiej Brytanii ocenę operacyjną rozpoczyna się od analizy otoczenia i przyczyn powstania sytuacji kryzysowej, w ramach której rozpatruje się:

- historię konfliktu,

- położenie geostrategiczne,

- środowisko fizyczne,

- infrastrukturę,

- spoleczeństwo,

- kulturę,

- media,

- prawo,

- politykę, ekonomię i sprawy socjalne.

Przyczyny kryzysów są często bardzo skomplikowane. Wiele z nich ma podłoże historyczne, ale pojawiają się też takie, które są wywołane przez sytuacje współczesne. Analiza powinna pełnić funkcję eksplanacyjną i tłumaczyć istotne zdarzenia i relacje, postrzegane przez jedną lub więcej stron, jako fundamentalne dla ich tożsamości lub jako decydujące momenty w ich historii. Zmiany przebiegu granic mogą przyczyniać się do wzrostu napięć i konfliktów. Podłoże historyczne wyjaśnia również ostatnie wydarzenia, które zapoczątkowały obecny kryzys.

Położenie geostrategiczne państwa, w ramach którego analizuje się: położenie geograficzne (łącznie ze stosunkami z sąsiadami), zasoby bogactw naturalnych (np. ropa naftowa) lub szczególne możliwości (takie jak posiadanie broni masowego rażenia).

Środowisko fizyczne, należy podzielić na następujące elementy: klimat i środowisko, geografię, hydrografię i oceanografię. Zmiany klimatyczne mogą powodować klęski żywiołowe (np. susze, powodzie itp.) co istotnie może wpływać na planowane działania poprzez ograniczony dostęp do infrastruktury drogowej, zasobów wody oraz poprzez wymuszone migracje ludności. Ukształtowanie terenu determinuje potencjalną aktywność sił w obszarze operacji. Warunki hydrograficzne i oceanograficzne ograniczają działania morskie, na wodach śródlądowych oraz w obszarach nadbrzeżnych. Istotnymi czynnikami w tym obszarze są też pogoda oraz pora roku, które należy poddać analizie, planując działania morskie i lądowe (ibidem: 18-31).

Stan infrastruktury może mieć znaczący wpływ na środowisko operacyjne, zarówno bezpośredni (np. jakość i ilość usług świadczonych na rzecz ludności, sił) oraz pośredni (np. możliwość udziału innych podmiotów, w ramach kompleksowego podejścia). Najważniejsze elementy to:

- sieć transportowa: drogi, kolej, żegluga, lotnictwo, porty i lotniska;

- energetyka: dostawy energii elektrycznej i jądrowej, węgla, ropy i gazu;

- komunikacja: Internet i telefonia (stacjonarna i mobilna);

- media: telewizja, radio i prasa;

- służba zdrowia: szpitale, kliniki, apteki;

- edukacja: szkoły podstawowe, średnie i wyższe;

- bezpieczeństwo: policja, wojsko, sądy, więzienia;

- przemysł: zbrojeniowy, chemiczny, nuklearny, elektroniczny i inne.

Niezwykle ważnym aspektem $\mathrm{w}$ kontekście planowania operacyjnego jest społeczeństwo. To od niego zależy sukces operacji. Ludność w obszarze operacji należy 
analizować, uwzględniając wyróżniki kulturowe, religijne, etniczne, demograficzne lub klasowe. Uwarunkowania etniczne ukazują charakterystyczne cechy kulturowe danej grupy, jej zwyczaje, obyczaje, język oraz zachowania. Ponadto granice etniczne, często inaczej przebiegające niż granice państw, mogą mieć zasadniczy wpływ na swobodę manewru w obszarze operacji. Do tego, język, który jest kluczowym elementem tożsamości narodowej czy grupowej. Należy wziąc również pod uwagę podział społeczeństwa pod względem np. zamożności lub wykonywanego zawodu.

Znajomość zasad międzykulturowych i wzajemnych interakcji obyczajów, sposobów postępowania i zachowania przestrzeganych $w$ obszarze operacji jest niezbędna nie tylko w procesie dowodzenia, ale również do właściwego przygotowania i wyszkolenia sił. W tym celu należy poddać analizie: różnice religijne, fundamentalizm, różnice kulturowe, obyczajowe, podejście do „obcego”, czy też czynnika wojskowego. Różnice w tych obszarach są istotne ze względu na cel operacji oraz wynikają najczęściej z różnic między środowiskami miejskim, wiejskim lub też z prezentowanych poglądów tradycyjnych, modernistycznych oraz alokacji zasobów determinujących jakość życia. Niektóre grupy społeczne charakteryzują się odmiennymi tradycjami, np. prowadzą koczowniczy tryb życia.

Zrozumienie roli mediów, pozwala na identyfikację teatru działań. Spełniają one podwójną rolę, stanowią źródło informacji dla miejscowej ludności i społeczności międzynarodowej, ale również kształtują opinie odbiorców lokalnych, regionalnych, a nawet globalnych.

Analiza obszaru prowadzonych działań, nie mogłaby być kompletna bez zastosowania prawa. System prawny danego państwa w sytuacji kryzysowej oraz wewnętrzne i międzynarodowe przepisy mające zastosowanie do wszystkich zaangażowanych sił.

Nie można również zapomnieć o polityce, ekonomii oraz sprawach socjalnych. Moga powodować niezadowolenie oraz sporadycznie konflikty społeczne. Główne elementy tych obszarów to: rząd, ekonomia oraz zorganizowane grupy przestępcze. Sprawowanie władzy zgodnie ze standardami międzynarodowymi może powodować sytuację kryzysową, w takich sytuacjach należy uwzględniać wpływy grup religijnych, etnicznych, plemiennych i innych, które odgrywają znaczącą rolę w społeczeństwie w obszarze operacji. Właściwe zidentyfikowanie potrzeb ekonomicznych regionu, państwa, społeczeństwa często decyduje o długotrwałej stabilizacji sytuacji w obszarze operacji. Ponadto należy dążyć do identyfikacji zorganizowanych grup przestępczych, które (w wielu państwach) mają wpływ na politykę, gospodarkę i struktury państwa, a tym samym na podejmowane decyzje.

Dokonując oceny operacyjnej, zgodnie z zapisami zawartymi w dokumentach doktrynalnych NATO, dowództwa analizują również źródła potęgujące rozwój kryzysu, do których zalicza się bogactwa naturalne. Mogą być one przyczyną konfliktów, bowiem dostęp do zasobów naturalnych może stanowić źródło finansowania dla różnych podmiotów lub też odcięcie od takich źródeł. Wpływ bogactw naturalnych na rozwój sytuacji kryzysowej będzie zależne od dostępności i łatwości ich eksploatacji. Źródłem może być też przebieg granic i linii podziałów oraz infrastruktura krytyczna i linie komunikacyjne. Ustanowione granice państwowe i wewnątrzpaństwowe, szczególnie te które nie uwzględniają obszarów spójnych etnicznie, plemiennie itp., często są przyczyną niezadowolenia społecznego. Dostęp lub jego brak do narodowej infra- 
struktury krytycznej oraz linii komunikacyjnych ma zasadniczy wpływ na rozwój sytuacji kryzysowej.

W omawianych czynnikach operacyjnych, osiagnięcie pożądanego celu polityczno-wojskowego wymaga cierpliwości oraz wytrwałości w trakcie prowadzenia działań. W kontekście walki ze zorganizowanym terroryzmem oraz grupą radykalnych islamistów, proklamujących własne państwo islamskie, wymaga również skoncentrowanego dążenia do osiągnięcia sukcesu, które musi uwzględniać zadania polityczne, wojskowe, ekonomiczne, kulturowe oraz społeczne (środowiskowe). $Z$ tego względu celowość jest niezmiernie ważna $w$ aspekcie wielokulturowości, bowiem sposób osiagnięcia celu operacji oraz prowadzonych działań może być wspomagany przez aspekty społeczno-kulturowe.

Wiarygodność jest podstawą budowy zaufania, przez którą siły koalicyjne prezentują szczerą, profesjonalna, efektywną postawę w trakcie prowadzenia operacji. Tak samo istotna jest jedność wysiłku, jak i jedność dowodzenia. Zastosowanie zasad obowiązujących w poszczególnych organizacjach wymaga spójności kierowania oraz dowodzenia. Dowodzenie wymaga określonego systemu działania, wzajemnych zależności, jasno sprecyzowanej roli oraz wzajemnie postanowionych zadań. Wspólny wysiłek buduje szereg kompleksowych działań, mających na celu spójne, wspólne, wiarygodne działanie kontyngentów wojskowych oraz sektora cywilnego. Dochodzi do szeregu interakcji w zakresie współpracy cywilno-wojskowej. Jedność celu, współpraca oraz poszanowanie własnych wartości powoduje skuteczne działanie na wszystkich szczeblach dowódezych oraz stanowi jedną z głównych zasad podejścia międzykulturowego.

Posiadanie mandatu do określonego działania jest również decydującym czynnikiem uzyskiwania poparcia na arenie międzynarodowej i uwiarygodnieniem legitymizacji działania $\mathrm{w}$ danym rejonie. Ogólna zgoda na przeprowadzenie działań operacyjnych staje się fundamentem wsparcia oraz współpracy między państwami sojuszniczymi. Zasada mandatu wynika głównie z postanowień prawnych i jest zgodna z nimi. Posiadanie mandatu wydawanego przez ONZ zwiększa liczbę sprzymierzeńców również spoza NATO („Przegląd Wojsk Lądowych”, 2008: 8).

Chcąc prowadzić działania zmierzające w kierunku zwycięstwa nad asymetrycznym przeciwnikiem wymagana jest „odpowiednia” ocena operacyjna. Analiza czynników, zawierających się w „ocenie operacyjnej” stanowi aktywne oraz potencjalne siły zaangażowane w zaistniałą sytuację kryzysową (pojawienie się tak zwanego Państwa Islamskiego), które wpływają na jej rozwój w sposób pozytywny lub negatywny, czasowy lub trwały. Większość kryzysów wywoływanych jest przez nagła zmiane zachowań uczestników społeczności w określonym regionie, państwie, obszarze. Dlatego też bardzo istotne jest zrozumienie relacji oraz motywacji do działania poszczególnych sił w obszarze operacji. Przeprowadzone badania wskazują, iż kategoryzuje się uczestników jako:

- przeciwnicy - najczęściej wrogo nastawieni, dążący do różnych celów - np. bojownicy Daesh;

- agresorzy - strony walczące ze sobą, paramilitarne grupy w obszarze Syrii i Iraku, Libii;

- neutralni - powstrzymujący się od aktywności, neutralni uczestnicy to np. organizacje międzynarodowe lub pozarządowe - mieszkańcy tak zwanego Kalifatu; 
- przeciwnicy zmian - czerpiący zyski z aktualnej sytuacji - państwa, ,gracze polityczni" oraz firmy zbrojeniowe etc.

Istnieje wiele różnych indywidualności, grup i organizacji w obszarze operacji, ich identyfikacja oraz zrozumienie roli, jaką odgrywają, może mieć kluczowe znaczenie dla osiągnięcia stanu końcowego. Do najważniejszych należą:

- kluczowi liderzy, którzy odgrywają najważniejszą rolę, najczęściej są to przywódcy polityczni, religijni, plemienni lub wojskowi działający samodzielnie lub w sposób zorganizowany. Należy dążyć do identyfikacji: rzeczywistych przywódców, struktur organizacyjnych, zaplecza politycznego, stylów kierowania, mocnych i słabych stron oraz wrażliwych punktów, celów i intencji:

- pozostałych liderów, gdzie oprócz najważniejszych podmiotów, liderzy podległych i współpracujących organizacji (lokalnych, regionalnych) mogą również odgrywać ważną rolę, można do nich zaliczyć:

1) „szare eminencje":

- partie polityczne i inne organizacje niepolityczne,

- przywódcy wojskowi i grupy zbrojne,

- władza tradycyjna (wodzowie plemienni, starszyzna),

- przywódcy organizacji religijnych:

2) ,popularne siły":

- społeczeństwo,

- populacja (wraz z uchodźcami),

- diaspory;

3) grupy biznesowe/handlowe ( np. wpływu terytorialnego):

- państwa sąsiedzkie,

- ambasady zagraniczne,

- organizacje regionalne, np.: Liga Arabska, Unia Afrykańska,

- międzynarodowe i pozarządowe organizacje (E1 Ghamari, 2015: 13-37).

Podsumowaniem analizy sił, jako czynnika operacyjnego, jest identyfikacja możliwości oraz stopnia oddziaływania na zaistniałą sytuację przez poszczególnych aktorów, co należy ustalić poprzez analizę:

- celi - mogą być bardzo ogólne lub ściśle sprecyzowane obejmujące sprawy lokalne, narodowe, regionalne, a nawet globalne;

- motywacji - zakres motywacji będzie się różnił w zależności od organizacji lub miejsca zajmowanego w organizacji, państwie, regionie itp.;

- nastawienia - różni uczestnicy moga prezentować różne postawy w stosunku do poszczególnych zagadnień, bez względu na interesy i cele innych;

- intencji - rozumiane jako plany bieżącej i krótkookresowej działalności;

- subkultury - zachowania wpływające na sposób osiaggania celów;

- powiązań, relacji, zależności - ukazują interakcje pomiędzy uczestnikami na różnych poziomach, ze szczególnym uwzględnieniem: zależności historycznych; aktualnych powiązań; możliwych przyszłych relacji w zmienionej sytuacji;

- zdolności - możliwość oddziaływania na sytuację, pozytywnie lub negatywnie. Zdolność uwzględnia siły i środki, zasoby, powiązania i sojusze w określonej sytuacji w określonym czasie; 
- wrażliwości - każdy z uczestników posiada słabe punkty, które są kluczowymi czynnikami w czasie analizy środków ciężkości.

Zapisy zawarte w dokumentach doktrynalnych Wielkiej Brytanii oraz innych dokumentach NATO, stanowią, że zrozumienie dlaczego w danej sytuacji doszło do użycia siły jest niezbędne do planowania i prowadzenia operacji. Czynniki, które spowodowały kryzys wskazują zarówno dlaczego zdarzenia miały miejsce oraz jaki mogą mieć wpływ w przyszłości. Analiza ich powinna obejmować: w jakim stopniu przyczyniły się do powstałej sytuacji, ich siłę i charakter oraz wzajemne powiązania. Jej wynik powinien przedstawiać jasny i zrozumiały obraz zaistniałej sytuacji opracowany w dowództwie poziomu operacyjnego. Wnioski z analizy, opracowane na podstawie różnych opinii, perspektyw i punktów widzenia, odpowiadają na pytania: co się dzieje, dlaczego tak się dzieje i co to może spowodować w przyszłości. Interakcje pomiędzy poszczególnymi czynnikami mogą powodować wiele konsekwencji, generując najbardziej prawdopodobne, najlepsze i najgorsze rozwiązania zaistniałej sytuacji, określając jednocześnie możliwe konsekwencje.

Analiza dokumentów doktrynalnych i regulaminów państw europejskich na przykładzie Niemiec i Wielkiej Brytanii pozwala wyciągnąć wnioski, że czynniki operacyjne są rozpatrywane w różny sposób. Należy jednak zauważyć, iż elementy podlegające szczegółowej ocenie, które mają zasadniczy wpływ na powstanie, rozwój i możliwości oddziaływania w określonej sytuacji kryzysowej zawierają się w tych samych obszarach. W dokumentach niemieckich istnieje jasny i czytelny podział czynników operacyjnych, elementy podlegające analizie sa pogrupowane w obszarach dotyczących przestrzeni, sił, czasu i informacji. W Wielkiej Brytanii, dokumenty dotyczące przebiegu procesu dowodzenia na poziomie operacyjnym takiego podziału nie zawierają. Tak kompleksowa analiza czynników operacyjnych realizowana jest w celu zrozumienia problemu w ramach oceny operacyjnej.

Efektem analizy czynników, które są kluczowe w zaistniałej sytuacji kryzysowej, niezależnie od przyjętego algorytmu postępowania oraz sposobu ich grupowania, w przedstawionych państwach europejskich, jest identyfikacja celów, ograniczeń i możliwości planowanej operacji.

\section{BIBLIOGRAFIA}

A.JP-3 Allied Joint Operations (2013), North Atlantic Treaty Organization, Allied Joint Publication, NATO Standardization Agency (NSA), NATO/OTAN.

AJP-5 Allied Joint Operational-Level Planning (2013), North Atlantic Treaty Organization, Allied Joint Publication, NATO Standardization Agency (NSA), NATO/OTAN.

AJP 5 Operational-Level Planning (2013), North Atlantic Treaty Organization, Allied Joint Publication, NATO Standardization Agency (NSA), NATO/OTAN.

AJP 5-00 Allied Joint Doctrine for Operational-Level Planning (2013), North Atlantic Treaty Organization, Allied Joint Publication, NATO Standardization Agency (NSA), NATO/OTAN.

Allied Command Operations Comprehensive Operations Planning Directive - Interim version 1.0 (2013), North Atlantic Treaty Organization, Allied Joint Publication, NATO Standardization Agency (NSA), NATO/OTAN. 
Allied Joint Doctrine AJP 3.4.I (2010), North Atlantic Treaty Organization, Allied Joint Publication, NATO Standardization Agency (NSA), NATO/OTAN.

Allied Joint Doctrine for Non-Article 5 Crisis Response Operations, A.IP-3.4(A) (2007), North Atlantic Treaty Organization, Allied Joint Publication, NATO Standardization Agency (NSA), NATO/OTAN.

Allied Joint Doctrine, AJP 01, Comprehensive Operations Planning Directive (COPD) (2010), North Atlantic Treaty Organization, Allied Joint Publication, NATO Standardization Agency (NSA), NATO/OTAN.

BMVg, Operative Leitlinie für Einsätze der Streitkräfte (1999), Bundeswehr, Bonn.

British Defence Doctrine (2013), $4^{\text {th }}$ Edition, North Atlantic Treaty Organization, NATO/OTAN.

Command and Control of Land Forces (TF) HDv 100/100 (2007), Federalne Ministerstwo Obrony, Bonn.

Doktryna operacyjna wielonarodowych polaczonych sit sojuszu (2010), AJP-1, North Atlantic Treaty Organization, Allied Joint Publication.

Defence Strategic Direction (2010), North Atlantic Treaty Organization, Allied Joint Publication.

El Ghamari M. (2015), Między kulturq̨ a religia, operacje wojskowe w Iraku i Afganistanie, Toruń.

Joint Doctrine Publication 5-00 (2008), JDP 5-00, North Atlantic Treaty Organization, Allied Joint Publication.

JDP 01 Campaigning (2010), $2^{\text {nd }}$ Edition, North Atlantic Treaty Organization, Allied Joint Publication. JDP 04 Understanding (2010), North Atlantic Treaty Organization, Allied Joint Publication.

JDP 2-00 Understanding and Intelligence Support to Joint Operations (2013), $3^{\text {rd }}$ Edition.

JDP 3-00 Campaign Execution (2010), $3^{\text {rd }}$ Edition, Change 1, North Atlantic Treaty Organization, Allied Joint Publication, NATO Standardization Agency (NSA), NATO/OTAN.

JDP 3-40 Security and Stabilisation: The Military Contribution (2012), North Atlantic Treaty Organization, Allied Joint Publication.

JDP 4-00 Logistics for Joint Operations (2014), $3^{\text {rd }}$ Edition, North Atlantic Treaty Organization, Allied Joint Publication.

JDP 6-00 Communications and Information Systems Support to Joint Operations (2013), $3{ }^{\text {rd }}$ Edition, Change 1, North Atlantic Treaty Organization, Allied Joint Publication, NATO Standardization Agency.

JDP 5-00 Allied Joint Publication (AJP)-01 (2010), Allied Joint Doctrine, NATO Standardization Agency (NSA), NATO/OTAN.

JDP 5-00 Campaign Planning (2008), Joint Doctrine Publication 5-00 (JDP 5-00), NATO Standardization Agency (NSA), NATO/OTAN.

„Przegląd Wojsk Lądowych” (2008), nr 7, styczeń.

Sun Tzu (1994), Sztuka wojny, Warszawa.

\section{STRESZCZENIE}

Główną przyczyną skłaniającą do podjęcia niniejszego tematu, było samouświadomienie problemów wynikających z postrzegania i definiowania czynników operacyjnych w sztuce wojennej, wobec potencjalnych operacji wojskowych przeciwko tak zwanemu Państwu Islamskiemu. Czynniki operacyjne nie posiadają jednoznacznego źródła ich definiowania i postrzegania w sztuce wojennej. Ich znaczenie w sztuce wojennej było i jest traktowane w wielu przypadkach instrumentalnie, stąd $w$ ich aspekcie opisywano zjawisko operacji lub przypisywano im tylko 
element opisu oceny środowiska prowadzenia przyszłych działań. Analiza znaczenia czynników operacyjnych wskazuje na ich szerszy zakres i znajduje swoje uzasadnienie w rozwoju myślenia operacyjnego w sztuce wojennej. Należy podkreślić, że zdolność myślenia operacyjnego jest kategorią psychologiczną związaną z rozwojem podmiotu myślenia. Natomiast połączenie procesu myślowego podmiotu $\mathrm{z}$ jego przedmiotem daje uzasadnioną podstawę do używania pojęcia myślenie operacyjne w sztuce wojennej.

Proces myślenia operacyjnego dotyczy związków i zależności pomiędzy postrzeganymi przedmiotami materialnymi sztuki wojennej i wpływem tych relacji na przygotowanie i organizowanie skutecznych działań. Zatem czynniki operacyjne stanowią podstawę rozwoju myślenia operacyjnego w sztuce wojennej. Identyfikacja materialnych przedmiotów sztuki wojennej jest podstawą do postrzegania wytwarzanych relacji. Należy posiadać świadomość, że w praktyce oznacza to prawidłową identyfikację rejonu prowadzonych działań oraz precyzyjne określenie stron, walczących. W opracowaniu sformułowano założenia współczesnego postrzegania i interpretowania czynników operacyjnych jako procesu inicjującego wszelkie działania zbrojne. W konkluzji należy stwierdzić, że przyjęty zakres oraz układ (struktura) pracy zdeterminowany został charakterem rozważanych problemów.

Slowa kluczowe: czynniki operacyjne, terroryzm, sztuka wojenna, dokumenty doktrynalne NATO, operacje wojskowe, myślenie operacyjne

\title{
INTERPRETATION OF OPERATIONAL FACTORS IN THE RULES AND DOCTRINES SELECTED COUNTRIES IN THE CONTEXT OF THE FIGHT AGAINST THE SO-CALLED ISLAMIC STATE
}

\begin{abstract}
The main reason, to take this subject was self-perception of the problems arising from the perception and definition of the operating factors in the art of war, to potential military operations against the so-called Islamic State. Operational factors do not have a clear source of their definition and perception of the art of war. Their importance in the art of war was and is treated in many cases instrumentally, their aspect of the phenomenon described operations or attributed to them only part of the description of environmental assessment to guide future actions. Analysis of the importance of operational factors indicating their wider range and finds its justification in the development of operational thinking in the art of war. It should be stressed that the ability to think of operating a psychological category entity associated with the development of thinking and mutual understanding. While the combination of thought process entity with its subject provides a reasonable basis for the use of the concept of thinking operating in the art of war.

The thinking process operating relates to compounds and the relationship between perceived material objects of art of war and the influence of these relations on the preparation and organization of effective action. Therefore operational factors are the basis for the development of operational thinking in the art of war. Identification of the material objects of art of war is essential to perceive the relationship produced. You must have the awareness that in practice this means the correct identification of the area of operations and precise description of the parties, fighting. The study formulates assumptions of contemporary perception and interpretation of operational factors as the process of initiating any military action. It must be concluded that the accepted scope and structure (structure) of the work was determined the nature of the problems under consideration.
\end{abstract}

Key words: operational factors, terrorism, warfare, documents doctrinal NATO military operations, operational thinking 